\title{
Bcl-2 Homologous Antagonist/Killer
}

National Cancer Institute

\section{Source}

National Cancer Institute. BCl-2 Homologous Antagonist/Killer. NCI Thesaurus. Code C21192.

$\mathrm{Bcl}-2$ homologous antagonist/killer (211 aa, $23 \mathrm{kDa}$ ) is encoded by the human BAK1 gene. This protein is involved in both protein-protein interactions and apoptosis. 